Archived version from NCDOCKS Institutional Repository http://libres.uncg.edu/ir/asu/

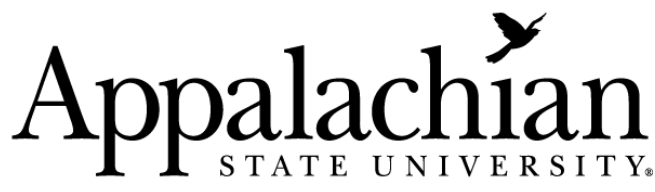 \\ B O O NE, NORTH CAROLINA
}

\section{Juggernaut In Kid Gloves: Inez Callaway Robb, 1900-1979}

\author{
By: Carolyn Edy
}

\begin{abstract}
Inez Callaway Robb, in her 50-year career as a reporter, society editor, WWII correspondent, and columnist, wrote more than 10,000 articles, syndicated to about 150 newspapers. By the 1950s, Inez Robb was a household name, and Robb was regularly billed as one of the world's top newspaper women. Yet, few people know her name today, and scholars largely have overlooked Robb's contributions to journalism. This biographical essay uncovers Robb's life and writings, while considering the apparent contradiction of her work, corresponding from more than 40 countries around the world, while advocating traditional gender roles and opposing an Equal Rights Amendment.
\end{abstract}

Edy, C. (2010) "Juggernaut In Kid Gloves: Inez Callaway Robb, 1900-1979." American Journalism, 27(4): 83-103 (ISSN: 0882-1127) Version Of Record Available At tandfonline.com 


\section{INTRODUCTION}

As a teenager whose parents refused to pay for silk stockings, Inez Callaway earned spending money writing society notes and proofreading copy for her local newspaper. It was 1916; she had never flown. The Idaho State Fair came to town, and a stunt pilot visited the Boise Capital News office in search of a passenger. The fifteen-year-old was the last one asked and the first to volunteer. She wrote about her barnstorming mission for the newspaper the next day, telling readers that flying was the only way a girl could stand on her head and still keep her dignity.1 Described as a "hell-kitten," "a regal lady of impeccable manners," "an astringenttongued newswoman," and "a juggernaut in kid-gloves," Inez Callaway Robb defied conventions and clung to them.2 In her fifty-year career as a reporter, society editor, war correspondent, and columnist, she wrote more than 10,000 articles, most of which were syndicated at least five days a week to about 150 newspapers nationwide. She was a lifelong Democrat whose written words battled what she saw as injustices of all kinds-including the equal rights amendment. Robb ardently opposed the ERA, and not just because she saw it as threatening the many incremental protections women had fought so hard to gain.3 Robb declared that she was "not a feminist or equal-righter," and she often wrote about the need to preserve and cherish what she saw as inherent differences between the sexes.4 Yet she was among the women reporters who, in the early 1930s and 1940s, began to turn the male-dominated newspaper world upside down. She did so within the perceived boundaries of her sex, so that few people noticed their perspectives had changed until the ride was over.

By 1938, Robb was among the highest-paid women reporters in the world.5 She became one of the first two women, in 1943, to travel with a U.S. military unit as accredited war correspondents. 6 By the 1950s, Inez Robb was a household name. She was regularly billed as one of the world's top newspaper women.7 Her columns could inspire hundreds of thousands of dollars in donations or an FBI inquiry.8 Yet, few people know Robb's name today, and scholars largely have overlooked her contributions to journalism. If mentioned at all, Robb appears in a few sentences, paragraphs or pages within works that celebrate women journalists who strived to avoid the society or women's pages or women journalists who helped fight for women's rights in and out of the newsroom.9

The story of an individual's life, as Alice Kessler-Harris noted, can be imagined not just "as a subject to be studied for its own sake, but as evidence that could provide a different path into the past."10 Journalism history scholars, until recently, often overlooked those women journalists whose work appeared in feature, society 
or women's sections, or in women's magazines.11 Instead scholars tended to focus on newspaper women who were successful in areas traditionally occupied by men-women who covered hard news topics and whose breaking-news stories regularly made the front page. Many stories remain to be told about the women who were on the "outskirts" of traditional journalism, whose lives offer a different perspective of journalism.12 The history of women in journalism must move beyond applying those "value systems which consider man the measure of significance" 13 and must seek to include stories of those women journalists who did not claim firsts for their sex or fight for women's equal rights, as well as stories about journalists and publications whose writings served women directly.14 Robb's story has not yet been fully told or examined for several reasons. Despite the prolificacy of Robb's writings for the general public, she wrote only superficially, if at all, about her private life. When she died in 1979, the few personal papers she left behind were kept by family members and not shared with the public.15 The women journalists who were alive when scholars took particular note of them, not surprisingly,w ere more likely to have their stories told. In 1986, the Washington Press Club began a project in which it ultimately gathered the oral histories of sixty women, all of whom were working or retired journalists, thus providing fodder for countless biographies and books on various aspects of women journalists.16 


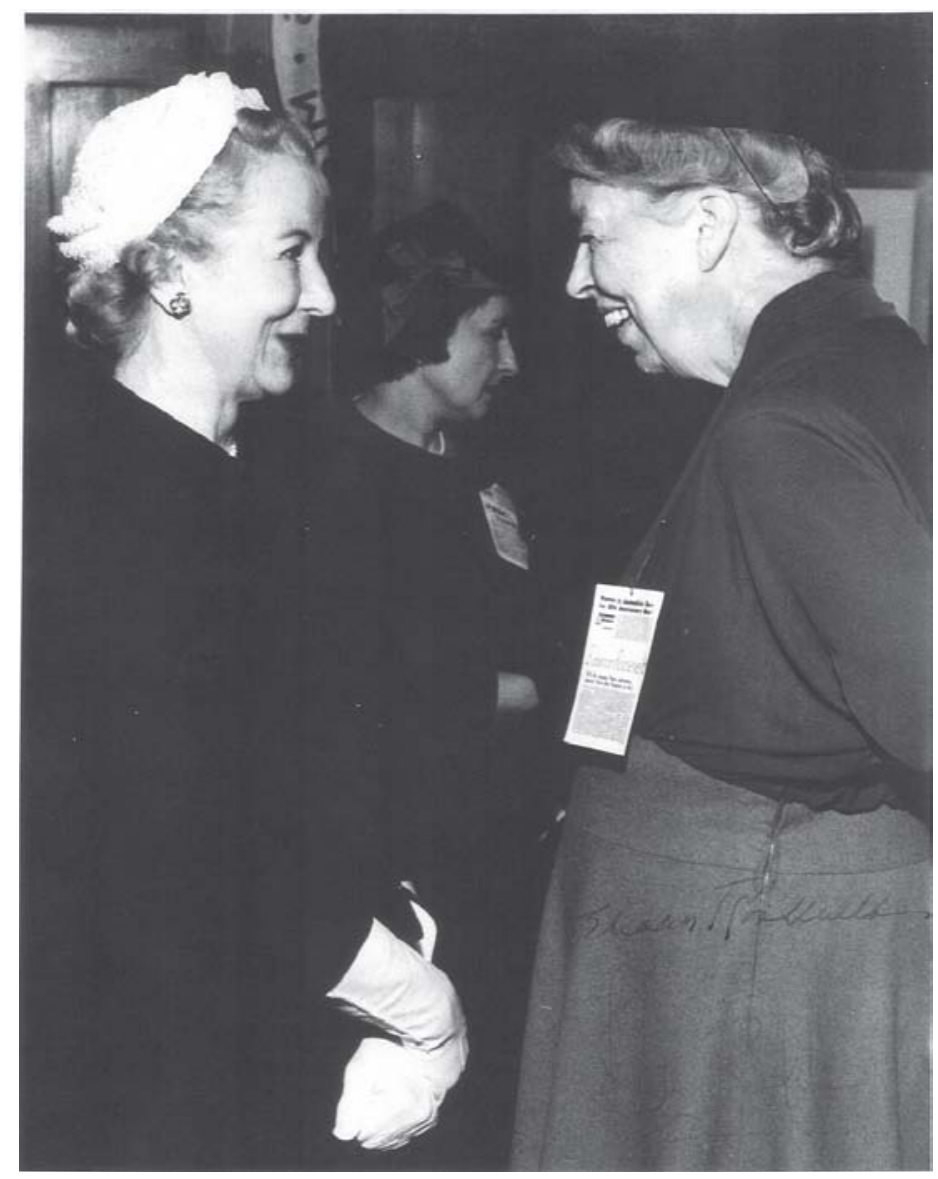

Inez Robb and Eleanor Roosevelt at the Women in Journalism Conference during the Missouri School of Journalism's 50th Anniversary, 1959. Credit: Photo by Noel E. Tomas. Used with permission.

In order to uncover and tell more fully the story of Robb's life, this article relied on a historical analysis that included the following materials: several hundred newspaper and magazine articles written by and about Robb; her book of humorous essays, Don't Just Stand There;17 correspondence from her former colleagues'manuscript collections; FBI documents; court documents detailing International News Service contracts; interviews with Robb's two nieces and information from the registrar and alumni offices at the University of Missouri and the University of Idaho. 


\section{BLUE EYES AND IRISH LUCK}

Robb, née Inez Early Callaway, was born in November 1900 in Middletown, California, but grew up in Caldwell, Idaho, a town of 4,000 people where her father was in a fruit-packing business and where she enjoyed a large, close-knit extended family life.18 She and her siblings (including a younger brother, Stephen, and younger sister, Cathryn) and cousins were encouraged by their elders to have opinions and share them-especially at the dinner table.19 Robb moved in with her aunt and uncle in Boise to attend high school. During her sophomore year, she applied for a job as a high school correspondent for the Boise Daily Capital.20 Robb later recalled, "I got the usual reply from the editor-'I want a boy, not a girl.' I told him I was just as good as any boy." 21 Throughout high school she wrote society notes and assisted with copy-editing, but the barnstorming mission was her first byline. "After I saw that by-line, nothing-not even wild editors - could have separated me from the newspaper business," she wrote in 1962.22

A straight-A student in high school, Robb won a full scholarship to attend the University of Idaho in 1918. She belonged to a sorority, wrote for two local newspapers and served on a campus committee charged with persuading the Idaho legislature to ratify the 19th amendment and grant women the right to vote.23 In 1920, Robb left the University of Idaho for the University of Missouri, where she completed a journalism degree in 1922.24 She returned to Idaho and worked as a reporter for the Idaho Daily Statesmen and the Nampa Free Press. Robb applied for a job at the Tulsa (Oklahoma) Daily World in 1924, at a time when the newspaper's owner was out of the country and much of the staff was out sick with the flu.25 "I was hired in desperation and against all rules," Robb later told a reporter.26 The city editor fought the owner to let Robb stay, arguing that she was a hard worker who "didn't take advantage of her sex."27

For twenty-seven months, Robb worked at the Tulsa World as a general assignment reporter.28 On her way home for a vacation, she stopped in Chicago and left a scrapbook of her news clips with the editor of the Chicago Tribune. He contacted her some time later to offer her a position at the Tribune's affiliated paper, the New York Daily News.29 Robb moved to New York in 1926 and began as a reporter for the Sunday section, where she soon doubled her previous salary.30 In 1928, when she was asked to fill a sudden opening as the society editor, Robb "wept oceans of tears" because at that time she shared "every reporter's contempt" for the society pages.31 Her editor convinced her to fill the role on a trial basis and encouraged her to cover the syndicated society column just as she'd covered news stories. She did so for twelve years, writing as Nancy Randolph, the column's nom de plume, bringing an investigative approach and a sense of humor to her writing that often meant her so-called society stories appeared as front-page news.32 In 1935, Robb explained 
how she inhabited the role without losing sight of her identity as a reporter:

In other words, we don't give a hang about Mrs. Vanderbilt giving a luncheon unless her guests include Al Capone and the Archbishop of Canterbury. Then that's news and a story. I modestly hope it has changed the conception of what a society page is. I think of myself as a reporter with a dash of columnist, but never, so help me God, as a society editor!33

Women reporters in the first half of the 20th century often broke into newspapers through the society or women's pages. The women who left for the news desk at the first opportunity rarely wanted to return to the lighter fare.34 Yet Robb found that she enjoyed using the newshound skills she'd gained in journalism school and at the Tulsa World in her society reporting. She quickly earned a reputation for adding depth to society writing with her news reporting skills and her habit of providing context from the news of the day, such as a story about a fear of Bolsheviks among Palm Beach elite.35 Robb claimed to attribute her accomplishments to her big blue eyes and a never-ending stash of clean white gloves, noting that her mother had said her success wasn't due to intelligence but to Irish luck.36 Her life off of the society pages had also taken a fortunate turn: in September 1929, shortly before her 29th birthday, she married Addison Robb, a public relations executive one-year her junior.37 Years later, she would playfully refer to him as her lord and master; she also called a husband like hers the best ingredient in any woman's life.38

After twelve years of society writing, Robb still acknowledged that no reporter wanted to be a society editor, but she was pragmatic about it. "This is an age of specialization in the newspaper field no less than any other," she said in her last days as Nancy Randolph. "It pays to be an expert."39 Robb's expertise certainly did pay off. In 1938, the International News Service lured Robb away from the Daily News, offering her $\$ 500$ a week and a syndicated column with her own name-and the world as her beat.40 She wrote seven articles a week, which International News Service described to the newspapers that ran her columns as "keen, sophisticated feature stories on current events and people in the news." 41

She continued to write both society stories and news stories throughout most of her career. Her writing swung easily from heavy news to society light-from Hitler's plans to use poison gas warfare to the jet set's desire to employ clairvoyants.42 Robb had discovered that she was comfortable covering high-society events, such as the wedding of the Duke of Windsor or the coronation of King George VI, and high-altitude events, such as a war plane ride through North Africa or the first round-the-world flight with the U.S. Army.43 (But not low altitude events: seasickness and claustrophobia overcame 
her aboard a submarine.)44 Even after she became a war correspondent, Robb wrote a mix of hard news stories and social commentary. First stationed in England to cover the war, she described how British women stayed busy during air raids. 45

Robb's mixing of hard news with human interest stories reflected what she thought readers desired and deserved. She spoke during "The Woman's Hour" at a convention of the American Society of Newspaper Editors in 1939, telling the roomful of male editors that they had reached a day "in which women's interests parallel men's interests more nearly than at any other time in the world." 46 She likened the women's pages, which she said showed women how best to run the business of making a home, to the finance pages, which she said showed men how best to run the business of making a living. The rest of the paper-the news and editorial content-needed to serve all readers, she said. She added that the women's pages should not condescend nor adopt a shrill tone, as they too often did. After Robb finished, the president of the association, William Allen White, referred to Robb and the other two women reporters speaking that morning as "three lovely little hell-cats." 47 It would be some time before newspaper editors heeded Robb's call to take women seriously as journalists or readers.48 Just as newspaper editors had relegated all things women to one hour of their multi-day annual convention, they worked to maintain gender divisions in their newsrooms and on the pages of their newspapers. 49

Despite the many women journalists striving to cover hard news and prove themselves equal to men, most women journalists were hired and tolerated because of their presumed differences from men. Robb wrote, in 1938, that women should not try to overcome these differences but should embrace them.

... I am not a feminist. ... I don't think that newspaper women should try to be good newspaper men. That is the idiotic goal of so many, who fall so far short. I am of the firm opinion that ... women ... should try to be good newspaper women. If nature hadn't intended the sexes to be different, it wouldn't have made them different. ... The majority will be far more successful if they try to be skillful newspaper women-not, of necessity, sob sister or cooking editors-but newspaper women who know their job, who can make their niche or find it. The field is wide open.50

Newspapers increasingly recognized the value of this field:

A woman's viewpoint could connect well with women readers, a woman might have more success drawing out certain sources, and a news woman still attracted readers as a rarity.51 Additionally, for some editors, as Linda Lumsden noted, the woman's angle could be "an essentialist, male-constructed category intended to keep women journalists and their readers in their place: at home and subservient to men."52 A close look at Robb's writing reveals how she used 
the woman's angle to expand roles available to women by feminizing those roles-changing the ways in which the roles were viewed rather than the ways in which women were viewed. Her stories sold her feminine point of view-and the point of view much of the nation was buying and perpetuating at that time to reconcile women working outside the home for the war effort.53 Whether she was encouraging women to work for national defense or writing about the work of a woman war correspondent, Robb continually emphasized women's femininity and the expansion and addition of roles to include women.

\section{DAINTY, PATIENT, AND BRIGHT AS A DOLLAR}

Just before Mother's Day in 1941, Robb went "behind the scenes of the national defense program to find out what kind of work America's 'Amazons'" were doing.54 She reported what she found in a series of nine articles syndicated to newspapers nationwide between May 5, 1941, and May 13, 1941.55 Robb stressed that the millions of working women were essential to the United States and its national defense program-echoing the propaganda of her time.56 After listing examples of jobs filled by women and women who fill such jobs, Robb elaborated on several of each. She wrote that women who worked in national defense came from all walks of life, and yet she portrayed only those workers whom she described as pretty, feminine, and diminutive, and those jobs that she deemed particularly suited to women-those requiring patience and small hands.57 Robb's continued assurance to readers of these workers' feminine traits reflected the tendency, noted by Joan Riviere in 1929, among some women to wear womanliness "as a mask, both to hide the possession of masculinity and to avert the reprisals expected if she was found to possess it."58 Robb stated in the first article of the series:

But it is also universally true, and important to remember, that women have not been hired to replace men. ... In the main, women have been hired for jobs for which nature herself has especially fitted them. Because woman's hands are small and her fingers nimble and dexterous, employers are finding her a godsend in the manufacture of delicate parts for planes, tanks, gas masks, guns, ammunition, ships, radios and parachutes. ... Her manual dexterity and her abiding patience are sung again and again by companies employing her in numbers to equip the democratic world to fight its life and death struggle for survival.59

Size mattered to Robb, who boasted that no tool or task was too delicate or gigantic for women to master. Women with small, nimble fingers stacked ball bearings for aviation instruments, assembled motors, or cut and sewed silk into giant parachutes. Women who were gifted in patience, judgment, and precision designed turbines, sculpted tire treads, built barrage balloons, or counted rivets. Robb 
noted that one woman was doll-sized; another weighed just 120 pounds. 60 When Robb was not talking size, she noted other physical attributes and personal qualities.61 The ball-bearing worker wore a "very becoming powder-blue rayon smock."62 The engineer who researched properties of aluminum used for airplanes was "as feminine as the fine handiwork to which she is devoted." 63 The president of a salvage steel company was an energetic woman with a passion for gay hats.64 An editor's note at the end of one of Robb's articles stated: "Tomorrow: A lovely blonde does a man-sized job."65 The next article revealed that the blonde was "beautiful and bright as a dollar"-a former beauty contest winner who managed electroplating contracts for government defense work.66 Around the plant, Robb wrote, this manager "wears a serviceable smock over her chic dark dresses. Her plant turns out products for the Army and Navy, but her fingernails are as long and red and polished as if she spent her days playing bridge."67

Robb's entire series reads differently than her work as either a news reporter or columnist.68 Instead, she adopted a patriotic tone that seemed to promote all mankind, womankind, and the great Uncle Sam-the same tone favored by wartime propaganda.69 Not only did she portray women doing the very things that the government needed them to be doing, she flattered them, highlighting their strengths and overlooking any weaknesses. Robb showed them serving their country, using their God-given talents and assets to fill in where men needed them most-without risking their own femininity, without damaging the masculinity or job security of American men. She quoted foremen and bosses who assured readers that their women workers were feminine, smart, well-mannered, and attractive, and that of course they were doing the more feminine jobs to which they were best suited. A company official told Robb that sealing gasoline tanks is "very much like dressmaking and requires the same patience and skill as embroidery. ... It is a delicate, painstaking job for which men have little aptitude."70 In the final article in the series, Robb claimed that she only found one negative story in all of her reporting. "Even it, viewed in the right light, is a tribute to the deadly efficiency with which woman masters the tools of industrygiven a chance," Robb wrote.71 One woman had become so adept at operating a 10-ton crane that she had to be fired, company officials told Robb. The woman liked to show off, using the crane's hook to lift workmen off the ground by their pants. 72

\section{WAR AND DOMESTICITY}

As a society editor, Robb had refused to write about any event she hadn't attended. This same professional standard led her to insist on covering the war on location. Late in 1941, International News Service finally granted Robb's wish. A week before the attack on Pearl Harbor, Robb was stationed in England.73 She would later explain: 
I had many reasons for wanting to see the war. ... Naturally, the strongest one was the fact that this was the biggest story of all. And then I felt that an American woman should observe what war meant. No woman in my memory had the faintest conception of its effects, although thousands of women in other lands had suffered from it. And someplace in my head was the realization that this war was a crucible for my generation and for the one behind us, the generation that provided the fighting men. I was groping for some possible symptom of what this devastation and violence would do to us.74

Robb traveled and reported throughout the United States, England, and Ireland for two years before earning official recognition as a war correspondent. 75 In 1943, Robb and Associated Press reporter Ruth Cowan became the first two women to be transported with a military unit as accredited war correspondents, or assimilated second lieutenants as they also were known.76 After being thoroughly screened by the FBI and thoroughly outfitted by the U.S. Army, Robb and Cowan spent three months in uniform with the Women's Auxiliary Army Corps at the Tunisian front. Robb was proud to be U.S. war correspondent Number 327 (out of about 600 official U.S. war correspondents at that time) and on her return said, "There is enough ham in all of us to love being called a war correspondent, but thank goodness, there isn't enough heel in us to think we are heroic." 77 The U.S. War Department did consider Robb heroic and included her among the 314 war correspondents who were honored in January 1946 with theater campaign ribbons for "outstanding and conspicuous service with the armed forces during difficult and hazardous combat conditions."78

Robb's first series of articles from North Africa ran under her own byline, and they were light and humorous, focused on the homemaking and practical aspects of the life of a woman traveling in a decidedly masculine world.79 Robb's tone throughout sounded as though she meant primarily to entertain and engage readers. International News Service packaged seven articles with the title "Woman War Correspondent" and with several cartoon images of a very feminine Robb at work. 80 The first of these articles opened with Robb's comparison of her life with the images of war correspondents in film and fiction. She joked that in her time at the North African theater she never captured Rommel nor even a third-rate spy, but she did have a greater triumph. She had "managed to survive in an unheated tent through part of February and March in the bitter cold of a North African winter."81

Articles written by others noted that Robb faced truly harrowing and life-threatening incidents while covering news at the front.82 Robb's own articles only gave detailed accounts of harmless, humorous fears and challenges-such as having to wear pants and an 
unflattering helmet. She mentioned the real threats briefly, without fully acknowledging them. She quipped about gathering with other war correspondents on "Bomb Bay," having to take their air raids "straight" because the only alcohol available was no stronger than ginger ale.83 She listed items she had to carry in case of gunshot wounds or chemical warfare.84 She noted that she managed to hold onto her "quaking pride and put up a bold front under aerial bombardment" and that she managed "by sheer willpower to be cool, calm and collected" during the German breakthrough when Marshal Rommel's "hot breath seemed literally scorching the back of my neck."85

The only fear Robb acknowledged in this series of articles was a fear of lice. She said that her lowest point came when she was in a "near panic" after being given powder to rid herself of lice, should she ever be so afflicted; she then assured readers that she never did need the powder.86 She recounted the trial of having to sleep in a bed with one sheet and one blanket-no top sheet, no pillowcase-at a hotel that only provided hot water two hours a day.87 Yet she noted that she learned quickly what a luxury those accommodations represented in North Africa, after having to spend nights in a frigid tent and bathe using only her helmet filled with water.

Two articles are almost entirely devoted to the eating habits of Robb and the troops, detailing the use of canned foods, the dearth of vegetables and the need to eat according to the military's meal schedule.88 Robb wrote of learning to wash laundry in her helmet and to fashion wool blankets into a makeshift bed roll.89 She assured readers that no matter the conditions, she always wore her lipstick. One cartoon showed her in military garb, on her knees in front of a tent peering into a small mirror she was holding in one hand, while washing her face with a cloth held in the other.90 Another cartoon showed her placing her helmet atop her head, while looking into a large mirror with a bemused expression.91

\section{AROUND THE GLOBE AND IN COUNTRY}

Shortly after returning from North Africa, Robb was involved in another, smaller battle. At an election night for the Overseas Press Club, to which she belonged and for which, fifteen years later, she would serve as vice president, Robb reportedly "flew into a rage and resigned 'over the insults to our sex!'”2 The group's president, Lowell Thomas, had said the group had too many women members. The Overseas Club refused Robb's resignation, and within days the matter between Robb and Thomas was reportedly "patched up."93 On her return from serving with the WAAC, Robb praised the women with whom she had served because, she noted, they neither demanded nor received special privileges, and they worked like men.94 She also spoke in favor of the U.S. Army drafting women 
to work for the war effort95 as she continued writing her column, now billed as "Assignment America." In all, she reported from 40 countries and from most, if not all, of the 50 states. Her first big assignment after the war ended was to embark on an around-theworld flight-151 hours, 23,342 miles-on the Globester to mark the return of tourism.96 Her next big assignment proved far more turbulent. Accompanied by two police officers, Robb arrived about 1:30 a.m. by taxicab at Galveston harbor to cover the Texas City explosion of 1947-which ultimately killed more than 600 people and injured more than 1,000. Robb and her travel companions, the cab driver and the two police officers, ran when they heard cries that the nearby ship was on fire. They were about 300 yards away when it exploded at 2:14 a.m., sending Robb flying into the dirt, killing one of the police officers, and destroying the taxicab. Robb filed her first news story about the explosion at 4 a.m. and a second story, about her own experiences being badly bruised and terrified, shortly after.97 Her steady reporting while covering the disaster was cited thereafter as testimony to her skill as a newspaper woman in the countless articles about Robb and at the many speaking events and award ceremonies Robb attended.

By the 1950s, Robb was writing regular features for magazines, such as Cosmopolitan, Vogue, and The Saturday Evening Post. She also made frequent appearances as a keynote speaker at national conventions and appeared regularly on television and radio shows, such as "Meet the Press," where she often served as one of the "grillers" who interviewed guests such as U.S. Sen. Joseph McCarthy, Special Assistant Attorney General Newbold Morris, and pollster George Gallup.98

In her syndicated column, Robb wrote frequently, perhaps jokingly, that she was an advocate of equal rights for men. The equal rights amendment was, she wrote in 1950, "a dastardly plot against American womanhood" that offered "the very dubious satisfaction of acknowledging that men are every bit as good as women," while leaving women on their own to pay restaurant bills, chase away burglars, and move furniture.99 These lighter opinion pieces were written cryptically, with a tongue-in-cheek tone that often obscured their sincerity and meaning. Yet Robb did clarify her stance against the ERA in a few columns, such as this passage she wrote in 1958:

The amendment would destroy all the legislation to protect women in industry and before the law that has been passed over the years by predominately male state legislatures. It would leave her wide open to the kind of industrial exploitation from which men have been trying to protect her for years. And I think the average woman needs such an amendment as she needs a hole in the head! Since I was 14, I have had a job in a preponderantly masculine profession, the newspaper world. Preponderantly? Shucks. It's the most in the male tradition. That's the chief reason I chose 
it! But to get ahead in my profession I have needed equal rights like warts! As far as I can discern-and my discernment has sometimes been likened to radar-I have never, but never, been discriminated against in my profession.100

Rather than being based on denial or dishonesty, Robb's statement that no one had discriminated against her likely was based on her belief that men treated her just as they should treat a woman. She made it clear throughout her life that women could expect men to treat them well, but women should not expect men to treat them as equals. During a 1952 talk to "career women" in Atlanta, Robb outlined rules for women who wanted to work in a man's world.101 She explained that a woman must never complain to her boss about her home life or to her husband about her work life. Otherwise, the boss would be justified in "giving her the gate," and the husband would rightly expect her "to come home to kitchen, church and children." While permitting the women in her audience to wear pants in the workplace (if the women were thin and didn't put their hands in their pockets), she insisted that they must never wear the pants at home, literally or figuratively - that was the man's role, and the woman's primary role was to serve him.102

Let us put first things first. Any woman with the sense God gave geese is happiest with a home and a husband. That is her natural destiny. If she can also manage a job, career or work that interests her-always without neglecting the husband and home-fine! Well and good; I'm all for her. That's me, in fact. I've never had an employer who didn't know that my husband and home came first. But as long as I continue to do satisfactory work for him, the boss has never objected. Bosses, you will find, also like women who put first things first.103

Her columns in the 1950s and 1960s often included shallower opinion pieces-those that appeared to require minimal reporting. While she still tackled more complex subjects, such as an undercover FBI agent's role in the murder of a black civil rights worker in Alabama, she also began to write more frequently about less serious topics, such as the care and keeping of a Brooklyn Dodgers fan (her husband).104 She often fixated on a topic and exhausted it over multiple columns, such as taxation and the state of the U.S. economy or how appalling it was for most women to wear slacks.105 Many of her lighter columns were published in 1962 in a collection entitled Don't Just Stand There.106

Robb announced her retirement early in 1969.107 By then, she had traveled more than a million miles by plane and had covered every presidential inauguration from 1933 to 1961, two royal weddings and two royal coronations, nine national political conventions, and the election and coronation of Pope Paul VI.108 She was reported to have interviewed just about anyone who was anyone in the United 
States and abroad-including General Charles de Gaulle twice and two successive Chilean presidents within twenty-four hours. She and Addison Robb had been married 50 years when he died of a heart attack early in 1979.109 She died three weeks later of complications from Parkinson's disease, though one obituary mentioned that her health had worsened rapidly because she was so depressed about her husband's unexpected death.110 She didn't mention Parkinson's disease in her columns or in articles in which she was interviewed, and it's unclear when she was diagnosed or how many people knew about her illness.

\section{CONCLUSION}

While Robb did not publicly fight the boundaries that faced women in their professional or private lives, nonetheless her words and her actions stretched those boundaries for journalists and their audiences. Throughout her life, Robb was recognized with awards and fame and the privileges of a well-paid reporter with a generous expense account. Yet, she is all but forgotten today. Robb's story is significant not because she was an example of the rare early-20thcentury woman journalist who smashed gender barriers, fought for equal rights, or proved herself worthy in a man's world. Instead, Robb was an example of those women who fought to succeed within the societal standards for women of her time and therefore expanded those standards to include spheres that previously had not been considered feminine.

Robb's apparent contradictions likely were among her many strengths. She had worked for women's suffrage and had stood up to editors who preferred to hire men, but publicly she spoke out for men and against women's rights. She was similar to a wolf in sheep's clothing - advocating traditional roles for women while forging a groundbreaking career, asserting that women were equal to men in intellect while opposing their equal treatment. Her career exceeded the dreams of many journalists. Thus, Robb was far more visible-and therefore her words were far more capable of being influential - than many accomplished reporters who had refused the lighter women's fare and toiled away on hard news stories at daily papers.

\section{ENDNOTES}

1 Inez Robb, Don't Just Stand There (New York: D. McKay Co., 1962); Gladys Rowley, "A Day with Inez Callaway Robb," Reno (NV) Evening Journal, March 23, 1939; "Journalism Graduate, Well-known Columnist Inez Robb Dies at 79," Columbia Missourian, April 7, 1979; "Girl from Boise," Time, September 26, 1938. 
2 American Society of Newspaper Editors, "Proceedings of the Convention," April 21, 1939; William Randolph Hearst Jr., "Best, Brightest: The Journalism Stars From The Hearst Galaxy All Managed to Stay Within Tolerable Limits of Human Behavior, But Sometimes Needed a Prayer to Do So," Times Union, Albany, NY, October 11, 1991; Mary V.R. Thayer, "Pat Expects Victory," The Washington Post, July 27, 1960 (Thayer noted that Robb's question to Pat Nixon went unanswered because it began, "Mrs. Roosevelt - "); "Juggernaut in Kid Gloves," Time, May 11, 1962.

3 Clara Snell Wolfe, "Women Push Equal Rights Amendment," El Paso (TX) Herald-Post, June 25, 1958; Inez Robb, "Big Loss for Women," The (Syracuse, NY) Post-Standard, April 15, 1958.

4 Betty Milburn, "Equal Rights No Good for Women, Says Columnist Robb," Tucson (AZ) Daily Citizen, April 13, 1969; Inez Robb, "'Taint So, She Says," Doylestown (PA) Intelligencer, February 2, 1950; Robb, Don't Just Stand There, 41; Inez Robb, "Our Women Should Club Men Over Convention Treatment," Albuquerque (NM)Tribune, August 22, 1956. (Robb rarely explained this opposition, joking instead about the importance of feminine privilege and the need to fight for equal rights for men, "the really fragile sex.")

5 "Newspaper Women Open 38th Annual Convention Friday," Mansfield (MA) News-Journal, October 27, 1938. The article said Robb was reportedly the highest-paid woman reporter in the world, earning \$500 a week plus expenses in her new contract with International News Service.

6 Robert William Desmond, Tides of War: World News Reporting (lowa City: University of lowa Press, 1984), 297-298; Ruth Cowan Nash, Interviewed by Margot Knight, Interview \#2 (Harper's Ferry, W.V.: Washington Press Club Foundation) March 21, 1988, 23-37; Inez Robb, "Woman War Correspondent," Washington Post, May 10, 1943; Lilya Wagner, Women War Correspondents of World War II (New York: Greenwood Press, 1989), 105.

7 "Famous Woman Columnist to Write for Readers of the Herald-Post," El Paso (TX) Herald-Post, October 27, 1953. This article announced the arrival of Robb's syndicated column, calling it "one of America's favorite newspaper features written by one of the world's best-known newspaper women."

8 United States Government Memoranda, May, 19, 1965, and May 25, 1965, from Mr. DeLoach to M.A. Jones. Subject: Inez Robb. The FBI investigated Robb after her columns about casinos in Miami, anti-communism literature, life in Russia, and the culpability of an undercover FBI agent who was present when Ku Klux Klan members murdered a woman; correspondence from the American Medical Center for Burma, Collection of the Manuscript Division, Library of Congress, between the medical center program officer, Fanny Ellison, and Inez Robb. Ellison reported that Robb's columns about the medical center had brought in a total of $\$ 269,000$ in donations, including 
money, drugs and equipment, as well as an ambulance for which the value was unknown.

9 Patricia Bradley, Women and the Press: The Struggle for Equality (Evanston, III.: Northwestern University Press, 2005), 185, 191, 211, 221; Julia Edwards, Women of the World: The Great Foreign Correspondents (Boston: Houghton Mifflin, 1988), 149, 150, 151, 153; Linda Lumsden, "The Essentialist Agenda of the 'Woman's Angle' in Cold War Washington: The Case of Associated Press Reporter Ruth Cowan," Journalism History 33, no.1 (Spring 2007): 2-13; Marion Marzolf, Up from the Footnote: A History of Women Journalists (New York: Hastings House, 1977), 72; Ishbel Ross, Ladies of the Press: The Story of Women in Journalism by an Insider (New York: Harper, 1936), 450-453; Nancy Caldwell Sorel, The Women Who Wrote the War (New York: Arcade Pub., 1999), 187-189; Wagner, Women War Correspondents, 105-108.

10 Alice Kessler-Harris, "Why Biography?" American Historical Review, 114, no. 3 (2009): 626.

11 Maurine Beasley, "Recent Directions for the Study of Women's History in American Journalism," Journalism Studies 2, no. 2 (2001): 207-220; Catherine L. Covert, "Journalism History and Women's Experience: A Problem in Conceptual Change," Journalism History 8:1 (Spring 1981): 2-6; Jan Whitt, Women in American Journalism: A New History (Urbana: University of Illinois Press, 2008).

12 Ibid.

13 Gerda Lerner, The Majority Finds Its Past: Placing Women in History (Chapel Hill: University of North Carolina Press, 1979), 150.

14 Beasley, "Recent Directions for the Study of Women's History in American Journalism"; Covert, "Journalism History and Women's Experience"; Whitt, Women in American Journalism.

15 Robb had no children, and her closest surviving relatives are her brother's three children. In October 2008, one of Robb's nieces reported that she had letters of celebrities and dignitaries who wrote to Robb; the other niece said she had some clippings and notebooks but that most had faded and were illegible. As of September 2010, the author had not gained access to these materials.

16 Penny Bender Fuchs, "Women in Journalism Oral History Collection of the Washington Press Club Foundation," Journalism History, 28 no. 4 (2003).

17 Robb, Don't Just Stand There.

18 Hawley, James. History of Idaho: The Gem of the Mountains (Chicago: S.J. Clarke, 1920), 205; Robb, Don't Just Stand There; Wagner, Women War Correspondents, 105. 
19 Hawley, History of Idaho, 205; Gay Pauley, "It Seems Everyone Has Praise for Inez Robb," Cedar Rapids (IA) Gazette, May 2, 1962; Robb, Don't Just Stand There.

20 Inez Robb, "Inez Robb Writes -30-," Idaho State Journal, January 31, 1969.

21 Jay Rogers, "Inez Robb's Round Trip to S.A. Beats 1-Way to the Moon," San Antonio (Texas) Express and News, April 17, 1960.

22 Robb, Don't Just Stand There, 3.

23 "University News Letter," Idaho Daily Statesman, December 14, 1919; Louise Rowlett, "Inez Calloway [sic], Former Boise, Idaho Gilr, [sic], Has Full Life as Society Editor of a New York Newspaper," Salt Lake [Salt Lake City UT] Tribune, February 9, 1936.

24 E-mail communication in October 2008 from registrar offices at the University of Idaho and the University of Missouri; in an essay published after Robb's death, professor Neil Bartlett claimed that Robb had wanted to major in psychology but hadn't because the school's smoking experiments required student participation and women weren't allowed to smoke on campus. Neil Bartlett, "Sometimes, When You Talk to Prospective Majors, They Listen," Teaching of Psychology 6, no. 3 (1979).

25 Inez Callaway Robb, "Nancy Randolph Tells All: A Society Editor with a Difference." The Anchora of Delta Gamma 52, no. 1 (1935) 25.

26 Randy Krehbiel, "Out of This World: To Name a Few ... ." Tulsa (OK) World, September 18, 2005.

27 Ibid.

28 E-mail communication in October 2008 from the registrar office at the University of Missouri; Robb, "Nancy Randolph Tells All, 26.

29 Ross, Ladies of the Press, 452.

30 Ibid.

31 Zoe Kincaid Brockman, "Unguarded Moments," The Gastonia (NC) Daily Gazette, January 21, 1938.

32 Brockman, "Unguarded Moments"; Ross, Ladies of the Press, 453.

33 Robb, "Nancy Randolph Tells All," 26.

34 Marzolf, Up from the Footnote.

35 Inez Robb, "Making Bolshevists at Palm Beach," New Republic, April 8, 1931. 
36 Rowley, "A Day With Inez Callaway Robb."

37 "Callaway-Robb," New York Times, September 4, 1929; Robb, Don't Just Stand There, 187.

38 Robb, Don't Just Stand There, 187.

39 Brockman, "Unguarded Moments."

40 "Newspaper Women Open 38th Annual Convention Friday," Mansfield (MA) News-Journal.

41 Associated Press v. the U.S. Vol. 5, Transcript of Record, filed April 13, 1944, 2379.

42 Inez Robb, "Pretender Otto Says Hitler Plans Tremendous Gas Attack," Washington Post, April 26, 1942; Inez Robb, "Clairvoyants Thrive in Wartime Capital," Washington Post, October 26, 1942.

43 Alfred Clark, "Inez Robb, an Ex-Columnist, Dies; Was a World War II Correspondent," New York Times, April 6, 1979; "ATC Plans Flights Around the World," New York Times, September 22, 1945; Robb, Don't Just Stand There, 217.

44 Inez Robb, "No Portholes? U.S. Submarine 'Sinks' Inez," Washington Post, May 7, 1939.

45 Inez Robb, "Woman War Correspondent," Washington Post, May 13, 1943.

46 William Allen White, "Proceedings of the Convention," American Society of Newspaper Editors, 1939.

47 Ibid.

48 See Gwyneth Mellinger, "Hellcats and Frivolous Hats: Women's Struggle against Gender Barriers in the ASNE," presented to American Journalism Historians Association, October 2, 2008; and Alf Pratte, "'A Tortuous Route Growing Up:' The Rise of Women in the American Society of Newspaper Editors," Journal of Women's History 6, no.1 (Spring 1994): 51-66.

49 Norman P. Lewis, "Cheesecake to Chief: Newspaper Editors' Slow Acceptance of Women," American Journalism 25, no. 2 (2008) 33-55.

50 Steve Weinberg, A Journalism of Humanity: A Candid History of the World's First Journalism School, 75-76.

51 Lumsden, "The Essentialist Agenda"; Linda Lumsden, "You're a Tough Guy, Mary-and a First-Rate Newspaperman: Gender and Women Journalists in the 1920s and 1930s," Journalism and Mass Communication Quarterly 72 (1995); Jean Lutes, Front Page Girls: Women Journalists in American Culture and Fiction, 1880-1930 (Ithaca, N.Y.: Cornell University 
Press, 2006); Linda Steiner, "Gender at Work: Early Accounts by Women Journalists," Journalism History 23, no.1 (1997) 2-12.

52 Lumsden, "The Essentialist Agenda," 2.

53 D'Ann Campbell, Women At War With America: Private Lives In A Patriotic Era (Cambridge, Mass.: Harvard University Press, 1984); Susan M. Hartmann, American Women in the 1940s: The Home Front and Beyond (Boston: Twayne Publishers, 1982); Ruth Milkman, "Redefining 'Women's Work': The Sexual Division of Labor in the Auto Industry during World War II," Feminist Studies 8 (1982): 337-72; Leila J. Rupp, Mobilizing Women For War: German And American Propaganda, 1939-1945 (Princeton, N.J: Princeton University Press).

54 Inez Robb, "Arms and the Women: Hand that Rocks the Cradle Now Guides Machine Tools," Washington Post, May 5, 1941. (Mother's Day was May 7,1941$)$.

55 Ibid; Inez Robb, "From Sewing to Tanks: Women's Nimble Fingers Excel in Fashioning Precision Parts for Defense Weapons," Washington Post, May 6, 1941; Inez Robb, "Perform Leading Roles in Defense: Women Prove Superiority of Brains Over Brawn in U.S. Armament Plants," Washington Post, May 7, 1941; Inez Robb, "Women Manage Factories, Design Equipment for Defense," Washington Post, May 8, 1941; Inez Robb, "America's Amazons: Man's Mastery of the Air Hinges on Woman's Patience," Washington Post, May 9, 1941; Inez Robb, "America's Amazons: Dainty Hands Drop Embroidering to Stitch Parachutes for Our Soldiers of the Skies," Washington Post, May 10, 1941; Inez Robb, "America's Amazons: Woman Helps Make Fighting Planes Safe," Washington Post, May 11, 1941; Inez Robb, "Women Aid in Speeding Ship Program," Washington Post, May 12, 1941; Inez Robb, "Women Help Protect U.S. From Gas War," Washington Post, May 13, 1941.

56 Ibid; Campbell, Women At War With America, 96-97; William H. Chafe, Women and Equality: Changing Patterns in American Culture (Cary, NC: Oxford University Press, 1978), 92; Hartmann, American Women, 55-56; Rupp, Mobilizing Women For War, 137-166; Bilge Yesil, "'Who Said This Is a Man's War?': Propaganda, Advertising Discourse and the Representation of War Worker Women During the Second World War," Media History 10 (2), 2004.

57 Robb, "Arms and the Women"; Robb, "From Sewing to Tanks"; Robb, "Perform Leading Roles in Defense"; Robb, "Women Manage Factories"; Robb, "America's Amazons: Man's Mastery"; Robb, "America's Amazons: Dainty Hands"; Robb, "America's Amazons: Woman Helps"; Robb, "Women Aid in Speeding Ship Program"; Robb, "Women Help Protect U.S."

58 Joan Riviere, "Womanliness as a Masquerade," in ed. Wendy Kolmar and Frances Bartkowski, Feminist Theory (New York: McGraw Hill, 2005), first published in The International Journal of Psychoanalysis, 10 (1929). 
59 Robb, "Arms and the Women."

60 Robb, “America's Amazons: Woman Helps”; Robb, “Women Manage Factories, Design Equipment for Defense."

61 Robb, "Arms and the Women"; Robb, "From Sewing to Tanks"; Robb, "Perform Leading Roles in Defense"; Robb, "Women Manage Factories"; Robb, "America's Amazons: Man's Mastery"; Robb, "America's Amazons: Dainty Hands"; Robb, "America's Amazons: Woman Helps"; Robb, "Women Aid in Speeding Ship Program"; Robb, "Women Help Protect U.S."

62 Robb, "Perform Leading Roles in Defense."

63 Robb, “America's Amazons: Woman Helps.”

64 Robb, "Women Aid in Speeding Ship Program."

65 Robb, "Perform Leading Roles in Defense."

66 Robb, "Women Manage Factories."

67 Ibid.

68 Robb, "Arms and the Women"; Robb, "From Sewing to Tanks"; Robb, "Perform Leading Roles in Defense"; Robb, "Women Manage Factories, Design Equipment for Defense"; Robb, "America's Amazons: Man's Mastery"; Robb, "America's Amazons: Dainty Hands"; Robb, "America's Amazons: Woman Helps"; Robb, "Women Aid in Speeding Ship Program"; Robb, "Women Help Protect U.S."

69 Campbell, Women At War With America, 96-97; Chafe, Women and Equality, 92; Hartmann, American Women, 55-56; Rupp, Mobilizing Women For

War, 137-166; Yesil, "Who Said This Is a Man's War?"

70 Robb, "Arms and the Women."

71 Robb, "Women Help Protect U.S."

72 Ibid.

73 Robb, “Woman War Correspondent," May 10, 1943.

74 "Inez Robb Reflects on Highlights of 40-Year [sic] Career," El Paso (TX) Herald Post, February 3, 1969.

75 "U.N. Press Club to Hear Writer," Reno (NV) Evening Gazette, Dec. 11, 1943.

76 Desmond, Tides of War, 297-298; Nash, Interviewed by Margot Knight, 23-37; Robb, "Woman War Correspondent," May 10, 1943; Wagner, Women War Correspondents, 105. 
77 Inez Robb, "INS Woman Scribe Now With WAACS," San Antonio (TX) Light, February 1, 1943; Walter Winchell, "Walter Winchell: The Man on Broadway," Syracuse (NY) Herald Journal, April 30, 1943.

78 U.S. War Department, Bureau of Public Relations, January 1946, "War Correspondents-Decorations and Awards"; U.S. War Department, "Cable Warx 29101," January 301945.

79 Robb, "Woman War Correspondent," May 10, 1943; Inez Robb, "Woman War Correspondent," Washington Post, May 11, 1943; Inez Robb, "Woman War Correspondent," Washington Post, May 12, 1943; Robb, "Woman War Correspondent," May 13, 1943; Inez Robb, "Woman War Correspondent," Washington Post, May 14, 1943; Inez Robb, "Woman War Correspondent," Washington Post, May 15, 1943; Inez Robb, "Woman War Correspondent," Washington Post, May 16, 1943; Inez Robb, "Woman War Correspondent," Washington Post, May 17, 1943.

80 Ibid.

81 Robb, "Woman War Correspondent," May 10, 1943.

82 Lieut. Col. Joseph B. Phillips, "Women War Reporters Prove Good Soldiers in N. Africa," Evening Times, Cumberland, MD, March 1, 1943.

83 Robb, "Woman War Correspondent," May 13, 1943.

84 Robb, “Woman War Correspondent," May 11, 1943.

85 Ibid.

86 Ibid.

87 Robb, "Woman War Correspondent," May 13, 1943.

88 Robb, "Woman War Correspondent," May 15, 1943; Robb, "Woman War Correspondent," May 16, 1943.

89 Robb, "Woman War Correspondent," May 14, 1943.

90 Robb, "Woman War Correspondent." May 10, 1943.

91 Robb, "Woman War Correspondent," May 11, 1943.

92 Walter Winchell, "Walter Winchell: The Man on Broadway," Wisconsin State Journal, April 28, 1943. In 1958, Robb was elected third vice president to the Overseas Press Club, a group that had women officers since its founding by a group of men and women correspondents in the mid-1930s.

93 Walter Winchell, "Walter Winchell: The Man on Broadway," Burlington (NC) Daily Times-News, May 3, 1943. 
94 "Would Draft Women." New York Times, July 21, 1943.

95 Ibid.

96 "Globester Off to Azores on 2d Leg of Flight." Chicago Daily Tribune, September 29, 1945. The "Globester" was "the first regular globe-circling air service" and was flown on the C-54 Douglas Skymaster, a forty-passenger, four-motored plane.

97 Inez Robb, "Texas Tragedy," Lowell (MA). Sun, April 17, 1947; Inez Robb, "The Next Thing I Knew I Was on the Ground, My Mouth Full of Dirt,"' Lowell Sun, April 17, 1947.

98 NBC Television Network, "Meet the Press" July 4, 1947; NBC Television Network, "Meet the Press" Nov. 15, 1948; NBC Television Network, "Meet the Press" March 2, 1952.

99 Inez Robb, "'Taint So, She Says," Doylestown (Pennsylvania) Intelligencer, February 2, 1950.

100 Robb, "Big Loss for Women."

101 International News Service, "Career Women Hear Inez Robb At Atlanta, Ga.," In New Castle (GA) News, October 10, 1952.

102 Ibid.

103 Ibid.

104 Robb, Don't Just Stand There, 167; Inez Robb, "Was FBI Man an Accessory to Murder of Mrs. Liuzzo?" El Paso (TX) Herald-Post, May 14, 1965.

105 Robb, Don't Just Stand There.

106 Inez Robb, "Hubby Announces Book of Cowering Columnist," El Paso (TX) Herald-Post, April 30, 1962. (The column had Inez Robb's byline but claimed that her husband, Addison Robb, had written it while she hid under the bed, feeling foolish for having written a book at her age, after she'd sworn she'd never write a book because too many people who have nothing to say have written too many books.)

107 Inez Robb, “Inez Robb Writes -30-," Idaho State Journal, January 31, 1969.

108 “Inez Robb Reflects.” February 3, 1969.

109 Clark, "Inez Robb, an Ex-Columnist, Dies."

110 United Press International, "Inez Robb," Chronicle-Telegram (Elyria, Ohio), April 6, 1979. 